\title{
Grand Design Pengelolaan Wilayah Perbatasan Negara Berbasis Pemenuhan Hak Asasi Manusia Warga Negara
}

\author{
Oleh : \\ Yahya Ahmad Zein ${ }^{1}$
}

\begin{abstract}
abstrak
Pengelolaan wilayah wilayah di Indonesia yang berbatasan langsung dengan Negara lain menjadi hal yang harus diperhatikan secara serius oleh pemerintah. Grand Design pengelolaan wilayah perbatasan tersebut sangat terkait erat dengan upaya percepatan pembangunan ekonomi, sosial, budaya, pertahanan dan keamanan yang di arahkan kepada peningkatan kesejahteraan masyarakat di wilayah perbatasan. Kompleksitas permasalahan di wilayah perbatasan dan memerlukan penyelesaian dengan cara komperhensif adalah Aspek Batas Wilayah Negara, Aspek Ekonomi, Aspek Sosial-budaya, Aspek Pertahanan dan Keamanan, Aspek Sumberdaya Alam dan Lingkungan, Aspek Kelembagaan dan Capacity Building. Tujuan utama pengelolaan perbatasan, yakni; (1) Menjaga integrasi NKRI sebagai amanat konstitusi, (2) Membangun kawasan perbatasan secara berimbang, terpadu, dan komprehensif untuk kesejahteraan rakyat; (3) Mengukuhkan kapasitas Indonesia di wilayah perbatasan dalam konteks persaingan global. Grand Design Pembangunan kawasan perbatasan dalam implementasi selama ini belum dilakukan secara terpadu dengan mengintegrasikan seluruh sektor, sehingga tujuan diatas belum tercapai secara keseluruhan. Upaya pemenuhan hak asasi manusiaa warga negara di wilayah perbatasan negara harus dilakukan pemerintah melalui program-program secara sistematis dan berkesinambungan
\end{abstract}

Kata kunci : pengelolaan, wilayah perbatasan, Hak Asasi Manusia

\section{Abstract}

Management of territories in Indonesia that directly borders other countries must be taken seriously by the government. The Grand Design for managing the border area is closely related to efforts for accelerating economic, social, cultural, defense, and security development to improve the border region welfare. The problems' complexity requires a complete solution that includes the State Boundary Aspects, Economic Aspects, Sociocultural Aspects, Defense and Security Aspects, Natural Resources, and Environmental Aspects, Institutional Aspects, and Capacity Building. The main objectives of border management, namely: (1) Maintaining the integration of the Republic of Indonesia as a constitutional mandate; (2) Building a balanced, integrated and comprehensive border area for the people's welfare; (3) Strengthening Indonesia's capacity in border areas in the context of global competition. Grand Design Development of the border region in the implementation has not carried out by integrating all sectors, so the objectives have not yet achieved. The efforts to fulfil the human rights of citizens in this area must be systematically and continuously carried out by the government through programs.

Keywords: Management, Border Areas, Human Rights

\footnotetext{
${ }^{1}$ Dosen Fakultas Hukum universitas borneo tarakan
} 


\section{Pendahuluan}

Membangun Indonesia dari Pinggiran sebagaimana yang tertuang dalam Rancangan Teknokratik RPJMN 2020-2024 pada dasarnya menjadi salah satu isu menarik dalam pengembangan kawasan perbatasan Negara. beberapa tahun terakhir ini memang isu pemngembangan kawasan perbatasan menjadi salah satu topik yang serius untuk di tanggani oleh pemerintah. Adanya persolalan-persoalan kesenjangan sosial, ekonomi dan kesejahteraan antara masyarakat perbatasan di Indonesia dan di Malaysia. Keputusan Mahkamah Internasional yang menetapkan kepemilikan Malaysia terhadap Pulau Sipadan-Ligitan serta terjadinya konflik batas laut, misalnya di Blok Ambala dan di perairan Natuna semakin menambah ramainya perbincangan masalah perbatasan baik di darat maupun laut.

Ramainya perbincangan tersebut kembali menegaskan Eksistensi Negara Kesatuan Republik Indonesia (NKRI) sebagai negara kepulauan,dimana NKRI sebagai negara kepulauan yang terdiri atas pulau besar dan kecil. Pulau-pulau tersebut dihubungkan oleh laut dan selat di Nusantara yang merupakan laut yurisdiksi nasional sehingga membentuk sebuah negara kepulauan². Keberadaan NKRI sebagai Negara kepulauan ini telah diakui oleh dunia melalui Konvensi Perserikatan BangsaBangsa Tentang Hukum Laut, United Nations Convention On The Law Of The Sea (UNCLOS 1982). ${ }^{3}$

Dalam rangka Grand Design Pengelolaan Wilayah Perbatasan Negara Beberapa isu strategis yang menunjukkan kompleksitas permasalahan di wilayah perbatasan dan memerlukan penyelesaian dengan cara komperhensif adalah:

1. Aspek Batas Wilayah Negara, permasalahan batas wilayah negara meliputi batas darat, batas laut (maritim), dan batas udara.

2. Aspek Ekonomi, cara pandang dan perlakuan terhadap daerah perbatasan di masa lalu menempatkan daerah perbatasan sebagai buffer zone pertahanan dan secara ekosob terkesan diperlakukan sebagai halaman belakang yang tertinggal.

2 Yurisdiksi Negara dalam hukum internasional publik adalah hak suatu Negara untuk mengatur atau mempengaruhi dengan langkah-langkah atau tindakan yang bersifat legislatif,eksekutif,atau yudikatif atas hak-hak individu,hak milik, atau harta kekayaan,perilakuperilaku atau peristiwa yang tidak semata-mata merupakan masalah dalam negeri. (lihat juga Sefriani, Hukum Internasional Suatu Pengantar, (Jakarta: Penerbit : Rajawali pers). 2010. hlm.232.

${ }^{3}$ Bagi Bangsa dan Negara Republik Indonesia, Konvensi ini mempunyai arti yang penting karena untuk pertama kalinya asas Negara Kepulauan yang selama dua puluh lima tahun secara terus menerus diperjuangkan oleh Indonesia, telah berhasil memperoleh pengakuan resmi masyarakat internasional. Pengakuan resmi asas Negara Kepulauan ini merupakan hal yang penting dalam rangka mewujudkan satu kesatuan wilayah sesuai dengan Deklarasi Djuanda 13 Desember 1957, dan Wawasan Nusantara sebagaimana termaktub dalam Ketetapan Majelis Permusyawaratan Rakyat tentang Garis-garis Besar Haluan Negara, yang menjadi dasar perwujudan bagi kepulauan Indonesia sebagai satu kesatuan politik, ekonomi, sosial budaya dan pertahanan keamanan. ( lihat juga Penjelasan Umum Undang-Undang Republik Indonesia Nomor 17 Tahun 1985 Tanggal 31 Desember 1985 Tentang Pengesahan United Nations Convention On The Law Of The Sea ) 
3. Aspek Sosial-budaya, kualitas sumberdaya manusia yang relatif rendah membuat nilai keunggulan kompetitif masyarakat perbatasan menjadi sangat rendah dan berakibat pada kendala dalam pengembangan ekonomi di kawasan perbatasan.

4. Aspek Pertahanan dan Keamanan, pertahanan dan keamanan di kawasan perbatasan wilayah negara, sangat erat hubungannya dengan status penyelesaian garis batas antar negara dan pembangunan di perbatasan. Terbatasnya jumlah aparat serta prasarana dan sarana pendukung operasi lapangan dalam rangka pelaksanaan kegiatan pertahanan keamanan di perbatasan negara, masih sangat kurang dan tidak sebanding dengan panjang garis batas yang harus diawasi. Sehingga persoalan-persoalan krusial yang sering muncul adalah pemindahan patok batas, kerusakan lingkungan, dan berbagai pelanggaran perbatasan, serta aktivitas ilegal lainnya.

5. Aspek Sumberdaya Alam dan Lingkungan, di beberapa kawasan perbatasan terjadi upaya pemanfaatan sumberdaya alam secara ilegal, tak terkendali, sehingga mengganggu keseimbangan ekosistem dan kelestarian lingkungan hidup. Sering dilaporkan terjadi polusi asap lintas batas, banjir, longsor, tsunami, dan degradasi pulau. Hal ini cukup sulit diatasi karena keterbatasan pengawasan pemerintah dan belum tegaknya supremasi hukum secara lugas, tegas, dan adil.

6. Aspek Kelembagaan dan Capacity Building, sejak diberlakukannya UndangUndang No. 22 Tahun 1999 tentang Pemerintahan Daerah, yang kemudian direvisi dengan Undang-Undang No. 32 tahun 2004 jo Undang-Undang No. 12 Tahun 2008 Tentang Perubahan Kedua Atas Undang-Undang No. 32 Tahun 2004 Tentang Pemerintahan Daerah, Maka pengelolaan kawasan perbatasan menjadi tanggung jawab bersama antara Pemerintah Pusat dan Pemerintah Daerah sesuai dengan prinsip urusan bersama (concurrence). Namun, Pemda belum cukup memiliki kapasitas yang memadai dalam pengelolaan kawasan perbatasan terutama terkait dengan permasalahan kewenangan wilayah administrasi dan kompleksitas pembangunan yang melibatkan banyak pihak dan sektor serta masih terjadinya tarik-menarik kewenangan antara pusat dan daerah dalam hal pelaksanaan berbagai rencana pembangunan dan pengelolaan kawasan perbatasan yang diatur oleh berbagai peraturan perundang-undangan yang tumpang tindih. Kerjasama antar negara juga sangat penting dalam pemecahan dan penangkalan berbagai pelanggaran hukum dan kedaulatan negara, seperti (transboundary illegal trading, illegal logging, illegal fishing, human trafficking), dan berbagai kegiatan penyelundupan lainnya. Hingga saat ini masih sering terjadi berbagai kejadian tersebut baik melalui perbatasan darat maupun perbatasan laut menandakan belum optimalnya kerjasama antar negara ini. ${ }^{4}$

4 Kemitraan Partership, Rekomendasi Kebijakan Pengelolaan Perbatasan Indonesia, (Jakarta: Penerbit : Kemitraan Bagi Pembaruan Tata Pemerintahan/Partnership). 2011. Tanpa halaman 
Grand Design Pembangunan kawasan perbatasan dalam implementasi selama ini belum dilakukan secara terpadu dengan mengintegrasikan seluruh sektor terkait. Salah satu hal yang sangat penting dalam hal ini adalah kebijakan pemerintahan dalam menangani masalah perbatasan, yakni jangan hanya menggunakan pendekatan keamanan semata dengan mengabaikan pendekatan kesejahteraan sehingga banyak warga perbatasan memiliki ketergantungan ekonomi dengan wilayah negara tetangga. Bahkan disisi lain rezim otonomi daerah ${ }^{5}$ juga menjadi salah satu unsur dalam realisasi pengembangan masyarakat di perbatasan melalui Grand Design pembangunan Kawasan Perbatasan yang berorientasi kepada pemenuhan hak Asasi warga negara di wilayah perbatasan.

\section{Design Regulasi Pengelolaan Wilayah Perbatasan Negara}

Design Regulasi Pengelolaan wilayah perbatasan dalam sistem hukum nasional Indonesia pada dasarnya dapat dilihat dari beberapa ketentuan perundangundangan di bawah ini :

\section{a. Undang-undang Nomor 43 Tahun 2008 tentang Wilayah Negara.}

Sebelum dikeluarkannya Undang-Undang Republik Indonesia No.43 Tahun 2008 tentang Wilayah Negara ini, pada prinsipnya pengelolaan perbatasan di Indonesia masih berpedoman pada dasar yuridis yang memiliki kekuatan generalis, dan bergantung kepada asfek internal dan asfek eksternal yang di hadapi oleh masing-masing wilayah perbatasan yang ada di Indonesia, sehingga tidak jarang terdapat berbagai macam perbedaan dalam pengaturan masing-masing wilayah perbatasan Indonesia yang di sesuaikan dengan spesifikasi masing-masing wilayah tersebut.

Keberadaan UU No.43 Tahun 2008 pada dasarnya merupakan pengejawantahan dari apa yang di amanatkan dalam UUD 1945 Negara Kesatuan Republik Indonesia yang menyatakan bahwa : "Negara Kesatuan Republik Indonesia adalah sebuah negara kepulauan yang berciri nusantara dengan wilayah yang batasbatas dan hak-haknya ditetapkan dengan undang-undang"6.

Ketentuan UUD 1945 yang mengamanatkan pembentukan undang-undang secara khusus terkait dengan wilayah negara tersebutlah yang kemudian melahirkan undang-undang nomor 43 Tahun 2008 dengan beberapa pertimbangan yakni 7:

a. Negara Kesatuan Republik Indonesia sebagai negara kepulauan yang berciri nusantara mempunyai kedaulatan atas wilayahnya serta memiliki hak-hak berdaulat di luar wilayah kedaulatannya dan kewenangan tertentu lainnya untuk

5 Pasal 18 Undang-Undang Dasar 1945 adalah merupakan dasar hukum penyelenggaraan otonomi daerah dengan memberikan kewenangan yang luas, nyata dan bertanggungjawab kepada Daerah. Landasan ini diperkuat lagi dengan Ketetapan MPR RI. No.XV/MPR/1998 tentang penyelenggaraan Otonomi Daerah, pengaturan, pembagian dan pemanfaatan sumber daya Nasional yang berkeadilan, serta Perimbangan Keuangan antara Pemerintah Pusat dan Daerah dalam kerangka Negara Kesatua Republik Indonesia.

${ }^{6}$ Lihat Pasal 25A UUD 1945 Bab IXA Tentang Wilayah Negara

${ }^{7}$ Lihat dasar pertimbangan pembentukan Undang-Undang Nomor 43 Tahun 2008 Tentang Wilayah Negara 
dikelola dan dimanfaatkan sebesar-besarnya bagi kesejahteraan dan kemakmuran rakyat Indonesia sebagaimana diamanatkan dalam UUD 1945 .

b. Pengaturan mengenai wilayah negara meliputi wilayah daratan, perairan pedalaman, perairan kepulauan dan laut teritorial beserta dasar laut, dan tanah di bawahnya, serta ruang udara di atasnya, termasuk seluruh sumber kekayaan yang terkandung di dalamnya;

c. Pengaturan wilayah negara tersebut dilakukan untuk memberikan kepastian hukum dan kejelasan kepada warga negara mengenai ruang lingkup wilayah negara, kewenangan pengelolaan wilayah negara, dan hak-hak berdaulat. negara berkepentingan untuk ikut mengatur pengelolaan dan pemanfaatan di laut bebas dan dasar laut internasional sesuai dengan hukum internasional.

Pokok-pokok kebijakan pengaturan persoalan wilayah perbatasan negara yang diatur dalam undang-undang nomor 43 Tahun 2008 meliputi hal-hal sebagai berikut:

1. Pengaturan Wilayah Negara dilaksanakan berdasarkan beberapa asas pokok meliputi: Asas kedaulatan, ${ }^{8}$. Asas Kebangsaan, ${ }^{9}$. Asas Kenusantaraan, ${ }^{10}$. Asas keadilan,11. Asas Keamanan,12. Asas Ketertiban,13. Asas Kerjasama, ${ }^{14}$. Asas Kemanfaatan, ${ }^{15}$. Asas Pengayoman, ${ }^{16}$.

2. Tujuan dari pengaturan wilayah negara adalah : $a$. Menjamin keutuhan wilayah negara, kedaulatan negara, dan ketertiban di kawasan perbatasan demi kepentingan kesejahteraan segenap bangsa; $b$. Menegakkan kedaulatan dan hakhak berdaulat; dan $c$. Mengatur pengelolaan dan pemanfaatan Wilayah negara dan kawasan perbatasan, termasuk pengawasan batas-batasnya ${ }^{17}$.

3. Ruang lingkup wilayah negara meliputi wilayah daratan, wilayah perairan pedalaman, perairan kepulauan, laut teritorial, dasar laut, dan tanah di bawahnya, serta ruang udara di atasnya termasuk seluruh sumber kekayaan yang terkandung

${ }^{8}$ Lihat Pasal 2 huruf a Penjelasan Undang-Undang Nomor 43 Tahun 2008 Tentang Wilayah Negara.

${ }^{9}$ Lihat Pasal 2 huruf b Penjelasan Undang-Undang Nomor 43 Tahun 2008 Tentang Wilayah Negara.

${ }^{10}$ Lihat Pasal 2 huruf c Penjelasan Undang-Undang Nomor 43 Tahun 2008 Tentang Wilayah Negara.

${ }^{11}$ Lihat Pasal 2 huruf d Penjelasan Undang-Undang Nomor 43 Tahun 2008 Tentang Wilayah Negara.

${ }^{12}$ Lihat Pasal 2 huruf e Penjelasan Undang-Undang Nomor 43 Tahun 2008 Tentang Wilayah Negara.

${ }^{13}$ Lihat Pasal 2 huruf f Penjelasan Undang-Undang Nomor 43 Tahun 2008 Tentang Wilayah Negara.

${ }^{14}$ Lihat Pasal 2 huruf g Penjelasan Undang-Undang Nomor 43 Tahun 2008 Tentang Wilayah Negara.

${ }^{15}$ Lihat Pasal 2 huruf h Penjelasan Undang-Undang Nomor 43 Tahun 2008 Tentang Wilayah Negara.

${ }^{16}$ Lihat Pasal 2 huruf i Penjelasan Undang-Undang Nomor 43 Tahun 2008 Tentang Wilayah Negara.

${ }^{17}$ Lihat Pasal 3 Undang-Undang Nomor 43 Tahun 2008 Tentang Wilayah Negara. 
di dalamnya ${ }^{18}$. Berkaitan dengan batas wilayah negara baik di darat, perairan, dasar laut maupun tanah di bawahnya serta ruang udara di atasnya penetapannya mengunakan dasar perjanjian bilateral dan/atau trilateral mengenai batas darat, batas laut, sedangkan batas udara serta berdasarkan peraturan perundangundangan dan hukum internasional 19 .

4. Hak-hak berdaulat negara Indonesia dan hak-hak lain di wilayah yurisdiksinya dalam pelaksanaannya disesuai dengan ketentuan peraturan perundangundangan dan hukum internasional ${ }^{20}$. Dalam menentukan batas Wilayah Yurisdiksi Indonesia yang berbatasan dengan wilayah yurisdiksi Australia, Filipina, India, Malaysia, Papua Nugini, Palau, Thailand, Timor Leste, dan Vietnam, termasuk titik-titik koordinatnya ditetapkan berdasarkan perjanjian bilateral dan/atau trilateral. Akan tetapi jika wilayah yurisdiksi Indonesia tersebut tidak berbatasan dengan negara lain, Indonesia menetapkan Batas wilayah yurisdiksinya secara unilateral berdasarkan ketentuan peraturan perundangundangan dan hukum internasional 21.

5. Kewenangan pemerintah dan pemerintah daerah dalam melakukan pengaturan pengelolaan dan pemanfaatan wilayah negara serta kawasan perbatasan 22, dimana dalam pengelolaan dan pemanfaatan tersebut pemerintah berwenang: $a$. Menetapkan kebijakan pengelolaan dan pemanfaatan wilayah negara dan kawasan perbatasan; $b$. Mengadakan perundingan dengan negara lain mengenai penetapan batas wilayah negara sesuai dengan ketentuan peraturan perundangundangan dan hukum internasional; $c$. Membangun atau membuat tanda batas wilayah negara; d.Melakukan pendataan dan pemberian nama pulau dan kepulauan serta unsur geografis lainnya; $e$.Memberikan izin kepada penerbangan internasional untuk melintasi wilayah udara teritorial pada jalur yang telah ditentukan dalam peraturan perundang-undangan; $f$.Memberikan izin lintas damai kepada kapal-kapal asing untuk melintasi laut teritorial dan perairan kepulauan pada jalur yang telah ditentukan dalam peraturan perundangundangan; g.Melaksanakan pengawasan di zona tambahan yang diperlukan untuk mencegah pelanggaran dan menghukum pelanggar peraturan perundangundangan di bidang bea cukai, fiskal, imigrasi, atau saniter di dalam wilayah negara atau laut teritorial; $h$. Menetapkan wilayah udara yang dilarang dilintasi oleh penerbangan internasional untuk pertahanan dan keamanan; i.Membuat dan memperbarui peta wilayah negara dan menyampaikannya kepada Dewan Perwakilan Rakyat sekurang-kurangnya setiap 5 (lima) tahun sekali; dan $j$. Menjaga keutuhan, kedaulatan, dan keamanan wilayah negara serta kawasan perbatasan. Adanya kewenangan yang di berikan kepada pemerintah dan

\footnotetext{
${ }^{18}$ Lihat Pasal 4 Undang-Undang Nomor 43 Tahun 2008 Tentang Wilayah Negara.

${ }^{19}$ Lihat Pasal 5 Undang-Undang Nomor 43 Tahun 2008 Tentang Wilayah Negara.

${ }^{20}$ Lihat Pasal 7 Undang-Undang Nomor 43 Tahun 2008 Tentang Wilayah Negara.

${ }^{21}$ Lihat Pasal 8 ayat 1,2,3 Undang-Undang Nomor 43 Tahun 2008 Tentang Wilayah Negara.

${ }^{22}$ Lihat Pasal 9 Undang-Undang Nomor 43 Tahun 2008 Tentang Wilayah Negara.
} 
pemerintah daerah tersebut memberikan juga kewajiban untuk menetapkan biaya pembangunan kawasan perbatasan, dan dalam rangka menjalankan kewenangannya, Pemerintah dapat menugasi pemerintah daerah untuk menjalankan kewenangannya dalam rangka tugas pembantuan sesuai dengan peraturan perundang-undangan ${ }^{23}$.

Pengelolaan wilayah negara dan kawasan perbatasan, pemerintah provinsi berwenang: $a$. Melaksanakan kebijakan pemerintah dan menetapkan kebijakan lainnya dalam rangka otonomi daerah dan tugas pembantuan; $b$. Melakukan koordinasi pembangunan di kawasan perbatasan; $c$. Melakukan pembangunan kawasan perbatasan antar-pemerintah daerah dan/atau antara pemerintah daerah dengan pihak ketiga; dan $d$. Melakukan pengawasan pelaksanaan pembangunan kawasan perbatasan yang dilaksanakan pemerintah Kabupaten/Kota 24. Sedangkan pemerintah Kabupaten/Kota di berikan kewenangan : a.Melaksanakan kebijakan Pemerintah dan menetapkan kebijakan lainnya dalam rangka otonomi daerah dan tugas pembantuan; $b$.Menjaga dan memelihara tanda batas; c.Melakukan koordinasi dalam rangka pelaksanaan tugas pembangunan di kawasan perbatasan di wilayahnya; dan d.Melakukan pembangunan kawasan perbatasan antar-pemerintah daerah dan/atau antara pemerintah daerah dengan pihak ketiga ${ }^{25}$. Dalam rangka melaksanakan kewenangan tersebut Pemerintah Propinsi dan Kabupaten/Kota berkewajiban menetapkan biaya pembangunan kawasan perbatasan.

6. Kelembagaan pada tingkat pusat dan daerah yang diberi kewenangan untuk melakukan penanganan kawasan perbatasan, dimana pemerintah dan pemerintah daerah membentuk badan pengelola perbatasan nasional dan badan pengelola perbatasan daerah, Badan pengelola ini dipimpin oleh seorang kepala badan yang bertanggung jawab kepada presiden atau kepala daerah sesuai dengan kewenangannya. ${ }^{26}$

7. Keterlibatan masyarakat dalam menjaga dan mempertahankan wilayah negara termasuk kawasan perbatasan, dalam hal ini Pemerintah dapat melibatkan peran serta masyarakat dalam pengelolaan kawasan perbatasan yang dilakukan dalam bentuk mengembangkan pembangunan kawasan perbatasan dan menjaga serta mempertahankan kawasan perbatasan ${ }^{27}$.

8. Larangan dan sanksi bagi setiap orang yang melakukan pelanggaran terkait dengan perbuatan upaya untuk menghilangkan, merusak, mengubah, atau memindahkan tanda-tanda batas negara, atau melakukan pengurangan luas Wilayah Negara, serta perbuatan yang menghilangkan, merusak, mengubah, Negara.

${ }^{23}$ Lihat Pasal 10 ayat 1,2,3 Undang-Undang Nomor 43 Tahun 2008 Tentang Wilayah

${ }^{24}$ Lihat Pasal 11 Undang-Undang Nomor 43 Tahun 2008 Tentang Wilayah Negara.

${ }^{25}$ Lihat Pasal 12 Undang-Undang Nomor 43 Tahun 2008 Tentang Wilayah Negara.

${ }^{26}$ Lihat Pasal 14,15,16,17 \& 18 Undang-Undang Nomor 43 Tahun 2008 Tentang Wilayah Negara. Negara.

${ }^{27}$ Lihat Pasal 19 ayat 1,2, \& 3 Undang-Undang Nomor 43 Tahun 2008 Tentang Wilayah 
memindahkan tanda-tanda batas atau melakukan tindakan lain yang mengakibatkan tanda-tanda batas tersebut tidak berfungsi lagi sebagaimana mestinya 28.

\section{b. Undang-undang nomor 3 Tahun 2002 tentang Pertahanan Negara}

Pengelolaan wilayah perbatasan negara pada prinsipnya aspek pertahanan merupakan faktor yang sangat hakiki dalam menjamin kelangsungan hidup suatu negara. Tanpa mampu mempertahankan diri terhadap ancaman dari luar negeri dan/atau dari dalam negeri, suatu negara tidak akan dapat mempertahankan keberadaannya. Bangsa Indonesia yang memproklamasikan kemerdekaannya pada tanggal 17 Agustus 1945 bertekad bulat untuk membela, mempertahankan, dan menegakkan kemerdekaan, serta kedaulatan negara dan bangsa berdasarkan Pancasila dan UUD $1945 . .^{29}$

Pandangan hidup yang tertuang dalam Pembukaan dan Batang Tubuh UUD 1945, bangsa Indonesia dalam penyelenggaraan pertahanan negara menganut prinsip: 30

a. Bangsa Indonesia berhak dan wajib membela serta mempertahankan kemerdekaan dan kedaulatan negara, keutuhan wilayah, dan keselamatan segenap bangsa dari segala ancaman;

b. Pembelaan negara yang diwujudkan dengan keikutsertaan dalam upaya pertahanan negara merupakan tanggung jawab dan kehormatan setiap warga negara. Oleh karena itu, tidak seorangpun warga negara boleh dihindarkan dari kewajiban ikut serta dalam pembelaan negara, kecuali ditentukan dengan undangundang. Dalam prinsip ini terkandung pengertian bahwa upaya pertahanan negara harus didasarkan pada kesadaran akan hak dan kewajiban warga negara serta keyakinan pada kekuatan sendiri;

c. Bangsa Indonesia cinta perdamaian, tetapi lebih cinta kepada kemerdekaan dan kedaulatannya. Penyelesaian pertikaian atau pertentangan yang timbul antara bangsa Indonesia dan bangsa lain akan selalu diusahakan melalui cara-cara damai. Bagi bangsa Indonesia, perang adalah jalan terakhir dan hanya dilakukan apabila semua usaha dan penyelesaian secara damai tidak berhasil. Prinsip ini menunjukkan pandangan bangsa Indonesia tentang perang dan damai;

d. Bangsa Indonesia menentang segala bentuk penjajahan dan menganut politik bebas aktif. Untuk karena itu, pertahanan negara ke luar bersifat defensive aktif yang berarti tidak agresif dan tidak ekspansif sejauh kepentingan nasional tidak terancam. Atas dasar sikap dan pandangan tersebut, bangsa Indonesia tidak terikat atau ikut serta dalam suatu pakta pertahanan dengan negara lain;

\footnotetext{
${ }^{28}$ Lihat Pasal 20 \& 21Undang-Undang Nomor 43 Tahun 2008 Tentang Wilayah Negara.

29 Lihat Bagian Umum Penjelasan Undang-undang Nomor 3 Tahun 2002 tentang Pertahanan Negara

${ }^{30}$ Ibid.
} 
e. Bentuk pertahanan negara bersifat semesta dalam arti melibatkan seluruh rakyat dan segenap sumber daya nasional, sarana dan prasarana nasional, serta seluruh wilayah negara sebagai satu kesatuan pertahanan;

f. Pertahanan negara disusun berdasarkan prinsip demokrasi, hak asasi manusia, kesejahteraan umum, lingkungan hidup, ketentuan hukum nasional, hukum internasional dan kebiasaan internasional, serta prinsip hidup berdampingan secara damai dengan memperhatikan kondisi geografis Indonesia sebagai negara kepulauan. Di samping prinsip tersebut, pertahanan negara juga memperhatikan prinsip kemerdekaan, kedaulatan, dan keadilan sosial.

Merujuk pada undang-undang nomor 3 Tahun 2002 tentang Pertahanan Negara maka Pengelolaan keamanan di wilayah perbatasan pada dasarnya masih bersifat umum dan hanya merupakan bagian dari tugas pokok saja dari tujuan pertahanan negara yakni untuk menjaga dan melindungi kedaulatan negara, keutuhan wilayah Negara Kesatuan Republik Indonesia, serta keselamatan segenap bangsa dari segala bentuk ancaman. ${ }^{31}$

Undang-undang pertahanan negara ini menyebutkan bahwa masalah pengelolaan keamanan khususnya di wilayah perbatasan haruslah melibatkan semua komponen dan instansi yang terkait dengan masalah pertahanan dan keamanan negara termasuk pemerintah daerah sebagaimana yang tertuang dalam Pasal 20 ayat (3) undang-undang nomor 3 Tahun 2002 yang menyatakan bahwa Pembangunan di daerah harus memperhatikan pembinaan kemampuan pertahanan. Dalam kaitannya dengan pembinaan kemampuan pertahanan ini maka pada dasarnya wilayah Indonesia termasuk wilayah perbatasan dapat dimanfaatkan untuk pembinaan kemampuan pertahanan dengan memperhatikan hak masyarakat dan peraturan perundang-undangan ${ }^{32}$.

\section{c. Undang-undang Nomor 17 Tahun 2007 Tentang Rencana Pembangunan Jangka Panjang Nasional Tahun 2005 - 2025}

Kebijakan pengembangan kawasan perbatasan pada dasarnya telah dirumuskan dalam Rencana Pembangunan Jangka Panjang (RPJP) Nasional 20052025, yang mana arah kebijakan pengembangan perbatasan meliputi dua hal berikut ini: 33

1. Wilayah-wilayah perbatasan akan dikembangkan dengan mengubah arah kebijakan pembangunan yang selama ini cenderung berorientasi ke dalam (inward-looking) menjadi berorientasi keluar (outward-looking) sehingga dapat dimanfaatkan sebagai pintu gerbang aktivitas ekonomi dan perdagangan dengan negara tetangga.

\footnotetext{
${ }^{31}$ Pasal 4 UU No.3 Tahun 2002 tentang Pertahanan Negara.

${ }^{32}$ Lihat Pasal 22 ayat (1) UU No.3 Tahun 2002 tentang Pertahanan Negara.

${ }^{33}$ Lampiran Undang-Undang Nomor 17 Tahun 2007 Tentang Rencana Pembangunan Jangka Panjang Nasional Tahun 2005 - 2025, Ketentuan 4, hlm 19.
} 
2. Pendekatan pembangunan dilakukan, selain menggunakan pendekatan bersifat keamanan, juga diperlukan pendekatan kesejahteraan, dengan perhatian khusus diarahkan bagi pengembangangan pulau-pulau kecil di perbatasan yang selama ini lepas dari perhatian.

Kebijakan ini di tindaklanjuti dengan Rencana Pembangunan Jangka Menengah (RPJM) Nasional 2010 - 2014, dimana Pemerintah melakukan penajaman prioritas pembangunan, yaitu melalui 11 prioritas nasional Kabinet Indonesia Bersatu II. Salah satu dari 11 prioritas tersebut adalah menempatkan daerah tertinggal, terdepan, terluar, dan pasca konflik sebagai daerah prioritas pembangunan. Arah kebijakan yang telah ditetapkan oleh Kabinet Indonesia Bersatu II ini adalah "Mempercepat Pembangunan Kawasan Perbatasan Di Berbagai Bidang Sebagai Beranda Depan Negara Dan Sebagai Pintu Gerbang Aktivitas Ekonomi Dan Perdagangan Dengannegara Tetangga Secara Terintegrasi Dan Berwawasan Lingkungan Untuk Meningkatkan Kesejahteraan Masyarakat Dan Menjamin Pertahanan Keamanan Nasional."34

Fokus sasaran dari kebijakan percepatan pembangunan pengelolaan wilayah perbatasan tersebut meliputi:

1. Penyelesaian dan penetapan batas wilayah negara;

2. Peningkatan upaya pertahanan, keamanan dan penegakan hukum;

3. Peningkatan pertumbuhan ekonomi kawasan perbatasan;

4. Peningkatan pelayanan sosial dasar termasuk pendidikan dan kesehatan;

5. Penguatan kapasitas kelembagaan dalam pengembangan kawasan perbatasan secara terintegrasi;

6. Peningkatan pembangunan sarana dan prasarana pendukung untuk masyarakat di kawasan perbatasan.

\section{d. Undang-undang Nomor 23 Tahun 2014 tentang Pemerintahan Daerah}

Kewenangan pengelolaan kawasan perbatasan negara dalam UU No.23 Tahun 2014 tentang Pemerintahan Daerah secara khusus diatur dalam BAB XVI Bagian Kedua tentang Kawasan Perbatasan Negara, ${ }^{35}$ dimana Kawasan perbatasan negara diartikan sebagai Kecamatan-Kecamatan terluar yang berbatasan langsung dengan negara lain, dan berkaitan dengana pengelolaan perbatasan di tegaskan bahwa Kewenangan Pemerintah Pusat di kawasan perbatasan meliputi seluruh kewenangan tentang pengelolaan dan pemanfaatan kawasan perbatasan sesuai dengan ketentuan peraturan perundang-undangan mengenai wilayah negara, dan Selain kewenangan tersebut Pemerintah Pusat juga di berikan kewenangan secara khusus untuk:

a. penetapan rencana detail tata ruang;

${ }^{34}$ Lihat Lampiran Peraturan Presiden Republik Indonesia Nomor 5 Tahun 2010 Tentang Rencana Pembangunan Jangka Menengah Nasional Tahun 2010 - 2014.

${ }^{35}$ Lihat Ketentuan Pasal 361 ayat 1 s/d 8 UU No.23 Tahun 2014 tentang Pemerintahan Daerah 
b. pengendalian dan izin pemanfaatan ruang; dan

c. pembangunan sarana dan prasarana kawasan.

Adapun kewenangan pemerintah daerah terbatas kepada pelimpahan kewenangan yang di berikan oleh Pemerintah Pusat kepada Gubernur sebagai wakil Pemerintah Pusat dalam rangka sebatas mengoordinasikan pelaksanaan pembangunan kawasan perbatasan berdasarkan pedoman yang ditetapkan oleh Pemerintah Pusat. Berkaitan dengan peran Bupati/Walikota dalam pengelolaan perbatasan hanya sebatas membantu gubernur sebagai wakil pemerintah pusat. Hal ini ditegaskan dalam Pasal 361 ayat (5) yang menyatakan bahwa :"Dalam mengoordinasikan pelaksanaan pembangunan kawasan perbatasan gubernur sebagai wakil Pemerintah Pusat dibantu oleh bupati/wali kota". Bupati/Walikota dalam memberikan bantuan pelaksanaan pembangunan kawasan perbatasan tersebut, pada prinsipnya dapat menugaskan camat di kawasan perbatasan.

Secara spesipik berkaitan dengan Pembentukan Kecamatan di kawasan perbatasan pada dasarnya juga telah diatur dalam UU No.23 Tahun 2014 dimana di jelaskan bahwa pembentukan Kecamatan di kawasan perbatasan haruslah ditetapkan dengan Perda Kabupaten/Kota setelah mendapatkan persetujuan dari Menteri, dan Susunan organisasi serta tata kerja Kecamatan di kawasan perbatasan maupun persyaratan dan tata cara pengangkatan camat ditetapkan dengan Peraturan Menteri setelah mendapat pertimbangan dari menteri yang menyelenggarakan urusan pemerintahan bidang pendayagunaan aparatur negara. ${ }^{36}$

Dengan demikian maka dapat kita lihat bahwasannya UU No.23 Tahun 2014 tentang Pemerintahan daerah memberikan penjelasan bahwa pengelolaan dan pembangunan kawasan perbatasan agar tidak tertinggal dengan kemajuan kawasan perbatasan di negara tetangga adalah kewajiban dari Pemerintah Pusat. Kewenangan selain ketentuan tersebut akan menjadi kewenangan Daerah sesuai dengan ketentuan peraturan perundang-undangan

\section{Grand Design Pengelolaan Wilayah Perbatasan Negara Berbasis Pemenuhan HAM}

Keberadaan Undang-Undang Nomor 43 Tahun 2008 tentang Wilayah Negara dan Peraturan Presiden Nomor 12 Tahun 2010 tentang Badan Nasional Pengelola Perbatasan, mengamanatkan perlunya perbatasan ditangani secara intensif dan terpadu melalui Badan Nasional Pengelola Perbatasan (BNPP). Adapun Perhatian khusus difokuskan pada 2 (dua) hal yang saling terkait dan bersinergi antara satu dengan yang lain dan dilaksanakan melalui instrumen pembangunan nasional dan daerah. Keterpaduan kebijakan, program, dan kegiatan antar pemangku kepentingan (stakeholders) merupakan prasyarat mutlak untuk merealisasi visi terwujudnya kawasan perbatasan sebagai beranda depan Negara Kesatuan Republik Indonesia yang aman, tertib, sejahtera, dan berkelanjutan.

\footnotetext{
${ }^{36}$ Lihat Pasal 362 ayat $1 \& 2$
} 
Lembaga pengelola batas wilayah negara dan kawasan perbatasan yakni BNPP, sebagaimana terefleksi dari tugas pokok dan fungsinya yang difokuskan pada 4 (empat) hal, yaitu: menetapkan kebijakan program, menetapkan rencana kebutuhan anggaran, mengoordinasikan pelaksanaan, serta mengevaluasi dan mengawasi pelaksanaan pengelolaan batas wilayah negara dan kawasan perbatasan. ${ }^{37}$

Berkaitan dengan Grand Design Pengelolaan Batas Wilayah Negara pada dasarnya telah diatur dalam Peraturan Badan Nasional Pengelola Perbatasan Nomor 1 Tahun 2011 Tentang Desain Besar Pengelolaan Batas Wilayah Negara Dan Kawasan Perbatasan Tahun 2011 - 2025, dimana dalam peraturan tersebut di jelaskan bahwasannya fokus pengelolaan wilayah dan kawasan perbatasan meliputi :38

a. Pengelolaan Batas Wilayah Negara ${ }^{39}$ Darat Dan Laut; Fokus pengelolaan batas wilayah negara darat dan laut ini meliputi: a. penetapan dan penegasan serta pembangunan dan pemeliharaan batas; b. pengelolaan pertahanan, keamanan dan hukum.

b. Pengelolaan Kawasan Perbatasan ${ }^{40}$ Darat Dan Laut; Fokus pengelolaan kawasan perbatasan darat dan laut ini meliputi: a.pertahanan, keamanan dan hukum; b.ekonomi kawasan; dan c. sosial dasar kawasan perbatasan.

Penyusunan Grand Design Pengelolaan atas Wilayah Negara dan Kawasan Perbatasan secara prinsipil diarahkan untuk mencapai tujuan utama pengelolaan perbatasan, yakni; (1) Menjaga integrasi NKRI sebagai amanat konstitusi, (2) Membangun kawasan perbatasan secara berimbang, terpadu, dan komprehensif untuk kesejahteraan rakyat; (3) Mengukuhkan kapasitas Indonesia di wilayah perbatasan dalam konteks persaingan global. Dengan demikian penyusunan grand design disusun dengan memperhatikan hal-hal sebagi berikut: ${ }^{41} 1$. Mengutamakan Kepentingan Strategis Nasional.2.Pengelolaan Perbatasan Berwawasan Global. 3. Integrasi Seluruh Aspek Perubahan Lingkungan Strategis. 4. Keterpaduan Hubungan Pusat dan Daerah. 5. Dinamika Politik Perbatasan.

${ }^{37}$ Lihat Pasal 15 Undang-Undang Nomor 43 Tahun 2008 Tentang Wilayah Negara.

${ }^{38}$ Lihat Pasal 4\&5 Peraturan Badan Nasional Pengelola Perbatasan Nomor 1 Tahun 2011 Tentang Desain Besar Pengelolaan Batas Wilayah Negara Dan Kawasan Perbatasan Tahun 2011 2025

${ }^{39}$ Wilayah negara adalah salah satu unsur negara yang merupakan satu kesatuan wilayah daratan, perairan pedalaman, perairan kepulauan dan laut teritorial beserta dasar laut dan tanah di bawahnya, serta ruang udara di atasnya, termasuk seluruh sumber kekayaan yang terkandung di dalamnya.

${ }^{40}$ Kawasan perbatasan adalah bagian dari wilayah negara yang terletak pada sisi dalam sepanjang batas wilayah Indonesia dengan negara lain, dalam hal batas wilayah negara di darat, kawasan perbatasan berada di kecamatan.

${ }^{41}$ Lihat lampiran Peraturan Badan Nasional Pengelola Perbatasan Nomor 1 Tahun 2011 Tentang Desain Besar Pengelolaan Batas Wilayah Negara Dan Kawasan Perbatasan Tahun 2011 2025. 
Konsep dasar pengelolaan batas wilayah negara dan kawasan perbatasan, disamping memperhatikan berbagai hal sebagaimana telah didiskripsikan tersebut, selanjutnya dikembangkan dengan mengacu pada pokok-pokok pikiran:

a. Pengelolaan Perbatasan dilakukan dengan Pendekatan secara Komprehensif Tiga Dimensi : Kesejahteraan, Keamanan, dan Lingkungan, Pengelolaan batas wilayah negara dan kawasan perbatasan, dilakukan dengan menggunakan pendekatan yang berorientasi pada kesejahteraan, yang dilaksanakan serasi dengan dua pendekatan lain yang berorientasi pada keamanan dan lingkungan.

b. Pengembangan Pusat Kegiatan Strategis Nasional (PKSN) sebagai entrypoint pembangunan kawasan perbatasan secara terpadu Dalam Peraturan Pemerintah Nomor 26 tahun 2008 tentang RTRW Nasional terdapat 26 PKSN yang ditetapkan untuk mendorong pengembangan kawasan negara, yang letaknya berada di wilayah administrasi pemerintahan daerah otonom provinsi dan kabupaten/kota tersebar di 11 provinsi. Mengingat keberadaannya yang demikian, maka pengelolaan wilayah perbatasan dan PKSN di dalamnya, tidak dapat dilepaskan dengan berbagai urusan pemerintahan yang menjadi kewenangan daerah otonom, baik provinsi mau pun kabupaten/kota.

c. Basis Manajemen Penanganan Perbatasan difokuskan pada Problem dan Wilayah (Area and Problem Focus) Pengelolaan batas wilayah negara dan kawasan perbatasan, dilakukan dengan prinsip manajemen berbasis wilayah (problem and area fokus), yang intinya adalah mengembangkan potensi kawasan dan memecahkan problem- problem strategis perbatasan di wilayah-wilayah konsentrasi pengembangan tertentu secara terpadu.

Secara garis besar, mengelola perbatasan memiliki ruang lingkup penanganan yang mencakup dua sasaran strategis yaitu $:^{42}$

1. Pengelolaan Batas Wilayah Negara, Pengelolaan batas wilayah pada dasarnya memuat Berbagai langkah strategis untuk menetapkan dan menegaskan batasbatas wilayah negara serta batas-batas terluar perairan yurisdiksi dengan negara tetangga, pengamanan batas wilayah di darat dan di laut, serta reformasi manajemen pengelolaan lintas batas. Sedangkan pengelolaan kawasan perbatasan pada dasarnya terkait dengan berbagai langkah strategis untuk meningkatan kesejahteraan masyarakat setempat melalui pembangunan wilayah secara berimbang dan berkelanjutan.

2. Pengelolaan Kawasan Perbatasan, Sasaran wilayah pengelolaan kawasan perbatasan diarahkan pada Wilayah-wilayah Konsentrasi Pengembangan (WKP), yaitu kabupaten/kota yang berada di dalam Cakupan Kawasan Perbatasan (CKP), baik yang berada di kawasan darat maupun laut. Penentuan prioritas WKP ditetapkan dengan memperhatikan isu-isu strategis di setiap WKP dalam aspek pertahanan, sosial budaya, dan ekonomi.

\footnotetext{
${ }^{42}$ Lihat lampiran Peraturan Badan Nasional Pengelola Perbatasan Nomor 1 Tahun 2011 Tentang Desain Besar Pengelolaan Batas Wilayah Negara Dan Kawasan Perbatasan Tahun 2011 2025.
} 
Sasaran jangka panjang pengelolaan batas wilayah negara dan kawasan perbatasan (2011-2025), secara umum dan kualitatif didesain dapat mencapai 5 (lima) sasaran yakni:

a. Adanya kemajuan yang signifikan terkait penetapan dan penegasan batas antar Negara dan batas-batas perairan yurisdiksi

b. Terjaga dan terpeliharanya batas-batas wilayah negara dengan baik demi menjamin tegaknya kedaulatan Negara.

c. Menurunnya pelanggaran hukum dan terpeliharanya lingkungan hidup di kawasan perbatasan;

d. Meningkatnya kesejahteraan masyarakat di seluruh lokasi prioritas kawasan perbatasan

e. Berfungsinya PKSN sebagai pusat pelayanan dan pertumbuhan di wilayahwilayah konsentrasi pengembangan perbatasan.

Untuk mewujudkan visi dan misi serta sasaran jangka panjang pengelolaan perbatasan sebagaimana yang dirumuskan tersebut, dilakukan dengan tujuh strategi dasar pengelolaan perbatasan, yang selanjutnya disebut dengan "Strategi 7 Re", yaitu :43

a. Reorientasi arah kebijakan pengelolaan perbatasan, Strategi reorientasi, pada prinsipnya mengubah arah kebijakan dari kecenderungan orientasi inward looking, ke orientasi outward looking sebagai pintu gerbang aktivitas ekonomi dan perdagangan dengan negara tetangga. Strategi reorientasi ini memiliki 3 (tiga) elemen strategi, yaitu : 1) Pengembangan Pendekatan Komprehensif Mengembangkan pendekatan kesejahteraan (prosperity approach), yang serasi dengan pendekatan keamanan (security approach) dan pendekatan lingkungan (environment approach) dalam pembangunan kawasan perbatasan. 2) Pengembangan Pusat Kegiatan Strategis Nasional Mengembangkan Pusat-pusat Kegiatan Strategis Nasional (PKSN) di kawasan perbatasan, sebagai entry point penggerak pertumbuhan bagi wilayah sekitar perbatasan negara,yang mencakup: pembangunan sarana dan prasarana, pengembangan pusat ekonomi perbatasan, dan peningkatan kesejahteraan masyarakat yang didukung sengan penguatan kapasitas dan pemberdayaan masyarakat setempat serta keterpaduan pengelolaan perbatasan. (3) Pengembangan Dukungan Kebijakan Mengembangkan kebijakan lintas sektoral yang lebih terfokus dan kondusif bagi dukungan terhadap PKSN, sesuai dinamika perkembangan dan perbedaan kebutuhan kawasan perbatasan darat dan perbatasan laut, yang menjadi modal awal bagi kawasan perbatasan sebagai pintu gerbang aktivitas ekonomi dan perdagangan dengan negara tetangga.

b. Reposisi peran strategis kawasan perbatasan, Strategi reposisi, pada prinsipnya mengubah posisi kawasan perbatasan sebagai "beranda belakang

${ }^{43}$ Lihat lampiran Peraturan Badan Nasional Pengelola Perbatasan Nomor 1 Tahun 2011 Tentang Desain Besar Pengelolaan Batas Wilayah Negara Dan Kawasan Perbatasan Tahun 2011 2025 . 
negara" menjadi "beranda depan negara" yang memiliki peran strategis pemacu perkembangan ekonomi regional maupun nasional..

c. Rekonsolidasi daya dukung pengelolaan perbatasan, Strategi rekonsolidasi, pada prinsipnya menata ulang daya dukung, kekuatan, dan peluang yang ada untuk dikonsolidasikan ulang agar secara efektif dan efisien mampu dioptimalkan untuk kepentingan perbatasan, baik dalam rangka percepatan penyelesaian batas wilayah negara maupun pembangunan perbatasan.

d. Reformulasi basis pemikiran dan pengaturan pengelolaan perbatasan, Strategi reformulasi, pada prinsipnya melakukan review dan merumuskan kembali basis pengelolaan perbatasan, yaitu dasar pijakan pemikiran dan pijakan normatifnya, untuk menjawab dinamika perkembangan kebutuhan perbatasan sesuai dengan paradigma baru pengelolaan perbatasan antar Negara dan kawasan perbatasan.

e. Restrukturisasi kewenangan pengelolaan perbatasan, Strategi restrukturisasi, pada prinsipnya memperjelas kewenangan dalam pengelolaan perbatasan atau kegiatan- kegiatan terkait perbatasan, baik dalam pengelolaan batas wilayah Negara maupun pembangunan kawasan perbatasan.

f. Revitalisasi kemitraan dan kerjasama perbatasan, Strategi revitalisasi, pada prinsipnya memperkuat jejaring kemitraan dan kerjasama percepatan penyelesaian permasalahan batas wilayah negara dan pembangunan kawasan perbatasan dengan memperhatikan aspek lingkungan dan kaidah-kaidah hubungan antara Negara.

g. Reformasi tata laksana pengelolaan perbatasan, Strategi reformasi, pada prinsipnya menata ulang dan menerapkan tata-laksana pengelolaan perbatasan secara konsisten sesuai prinsip-prinsip akuntabilitas, transparansi, dan partisipasi masyarakat dalam upaya mewujudkan tata pemerintahan yang baik (good governance), di dukung dengan kemajuan teknologi informasi terkini, yang terus berkembang dalam skala global dan nasional.

Grand Design pengelolaan wilayah perbatasan tersebut sangat terkait erat dengan upaya percepatan pembangunan ekonomi, sosial, budaya, pertahanan dan keamanan yang di arahkan kepada peningkatan kesejahteraan masyarakat di wilayah perbatasan. Dengan demikian pengelolaan perbatasan harus berbasis pada permasalahan yang ada di wilayah perbatasan dan haruslah di sandarkan pada pemenuhan HAM warga negara. Secara umum pada prinsipnya dalam pengelolaan wilayah perbatasan di perlukan suatu pola atau kerangka penanganan yang menyeluruh meliputi berbagai sektor pembangunan serta koordinasi dan kerjasama yang efektif dari semua pihak baik pemerintah pusat maupun pemerintah daerah. Pola penanganan tersebut dapat di laksanakan sebagai suatu kebijakan makro maupun mikro dan disusun berdasarkan proses partisipasi semua pihak. Akan tetapi berdasarkan dua fakta persoalan utama di wilayah perbatasan tersebut maka pengelolaan wilayah perbatasan negara selayaknya di sandarkan kepada pemenuhan Hak Warga Negara. 
Upaya pemenuhan hak warga negara di wilayah perbatasan negara harus dilakukan pemerintah melalui program-program secara sistematis dan berkesinambungan.

Kerangka hukum hak asasi manusia (HAM) menempatkan negara (state) merupakan aktor utama yang memegang kewajiban dan tanggung jawab (duty holders) memenuhi HAM, sementara masyarakat merupakan pemegang hak (rights holders). Masyarakat di perbatasan pada prindipnya memiliki hak menuntut pemenuhan HAM, karena negara berkewajiban memenuhinya. Relasi keduanya dituangkan dalam sebuah bentuk kontrak sosial bernama konstitusi, yang di Indonesia disebut UUD 1945.

Pengelolaan wilayah perbatasan yang tidak di sandarkan pada pemenuhan hak maka akan mengakibatkan mata rantai kemiskinan di wilayah perbatasan yang tidak akan berujung. Jika mata rantai ini tidak diputus, maka generasi berganti generasi pun akan tetap didera kemiskinan,sehingga wilayah perbatasan akan tetap menjadi wilayah yang Terdepan,Tertinggal,Terluar dan Termiskin. Oleh karena itu untuk menghindari hal ini maka di sinilah peran pemerintah untuk memberikan jaminan pemenuhan hak atas pendidikan di wilayah perbatasan negara sebagai sarana untuk memutus mata rantai kemiskinan dan menciptakan kesejahteraan warga negara di wilayah perbatasan.

\section{Kesimpulan}

Bahwasannya fokus Grand Design pengelolaan wilayah dan kawasan perbatasan meliputi : pengelolaan wilayah perbatasan dengan mengubah arah kebijakan pembangunan yang berorientasi ke dalam (inward-looking) menjadi berorientasi keluar (outward-looking) sehingga dapat dimanfaatkan sebagai pintu gerbang aktivitas ekonomi dan perdagangan dengan negara tetangga dan pendekatan yang digunakan meliputi Tiga Dimensi yakni Kesejahteraan, Keamanan, dan Lingkungan. Serta Penyusunan Grand Design Pengelolaan atas Wilayah Negara dan Kawasan Perbatasan diarahkan untuk mencapai tujuan utama pengelolaan perbatasan, yakni; (1) Menjaga integrasi NKRI sebagai amanat konstitusi, (2) Membangun kawasan perbatasan secara berimbang, terpadu, dan komprehensif untuk kesejahteraan rakyat; (3) Mengukuhkan kapasitas Indonesia di wilayah perbatasan dalam konteks persaingan global.

\section{Rekomendasi}

Penelitian ini merekomendasikan; Hendaknya Grand design Pengelolaan wilayah perbatasan harus sejalan dengan upaya percepatan pembangunan ekonomi, sosial, budaya, pertahanan dan keamanan yang di arahkan kepada peningkatan kesejahteraan masyarakat berorientasi pada pemenuhan HAM sebagai hak konstitusional warga negara,sehingga dengan terpenuhinya hak tersebut akan memutus mata rantai kemiskinan, dengan demikian akan memperkuat orientasi pengelolaan wilayah perbatasan berbasis pada Pendekatan kesejahteraan (prosperity approach) 


\section{Daftar Pustaka}

\section{Buku-Buku}

Aderso, James E, Public Policy Making, New York: Praeger Publishers, 1979.

Affandi, Mochtar, Ilmu-Ilmu Negara, Bandung: Alumni, 1971.

Ardiwisastra Yudha, Bhakti, Imunitas Kedaulatan Negara di Forum Pengadilan Asing, Bandung: Alumni, 1991.

Ata Ujan, Andre, Keadilan \& Demokrasi, Yogyakarta : Kanisius,2001.

Aust, Anthony, Handbook of International Law, United Kingdom: CambridgeUniversity Press, 2005.

Azhary, Negara Hukum Indonesia Analisis Yuridis Normatif tentang Unsur-unsurnya, Jakarta : UI Press. 1995.

Badan Nasional Pengelola Perbatasan, Grand Design Pengelolaan Batas Wilayah Negara Dan Kawasan Perbatasan Di Indonesia Tahun 2011 - 2025, Jakarta.

Bakry, Noor Ms, Orientasi Filsafat Pancasila, Yogyakarta: Liberty,1997.

Black, Hendry Campbell, Black Law Dictionery, St Paul Minn : West Publishing, 1970.

Bodenheimer, Edgar, Jurisprudence, The Philosophy and Method of the Law, Cambridge Mass: Harvard University press, 1974.

Brien, John o,International Law, London: Cavendish, 2001.

Brownlie, Ian, Principles Of Public International Law, Oxford: Clarendon press, 1992.

Danusaoutro, St.Munadjat, Wawasan Nusantara (dalam pendidikan dan kebudayaan), Buku III, Bandung: Alumni, 1983.

- - -. Wawasan Nusantara (Dalam Implementasi Dan Implikasi Hukumnya), Bandung: 1982.

Direktorat Jenderal Strategi Pertahanan Direktorat Wilayah Pertahanan, Optimalisasi pengelolaan wilayah perbatasan maritime RI-PNG dalam rangka menjaga keutuhan NKRI, Jakarta: Departemen Pertahanan RI, 2007.

Direktorat Topografi Angkatan darat, Rencana Strategis Pengelolaan Batas Wilayah Darat RI 2010-2014, Jakarta: Direktorat Topografi Angkatan Darat, 2011.

E. Aderson, James, Public Policy Making, New York: Praeger Publishers, 1979. 
Farouk Ishak, Awang, Strategi Pembangunan Kawasan Perbatasan Kalimantan Timur, Samarinda : Pemerintah Propoinsi Kalimantan Timur : 2009.

Fachrurozy, Djawir et al., Kajian Akademik Masalah Batas Daratan Indonesia - Timor Larosae dalam Mengoptimalkan Peran dan Fungsi Survei Pemetaan Dalam Pengelolaan Batas Wilayah, Bakosurtunal berkerjasama dengan Depdagri, Forum Komunikasi dan Koordinasi Teknis Bata Wilayah, Bogor, 2002.

Gamer, J.W. dan Samidjo, Ilmu Negara, Bandung: Armico,1986.

Harsthorne, Sugestion of the terminology of political boundaries, AAAG, Vol.26, 1936.

Hartono, C.F.G.Sunaryati, Politik Hukum Menuju Satu Sistem Hukum Nasional, Bandung: Alumni, 1991.

Haryomataram, KGPH, Pengantar hukum internasional, Jakarta : Raja Grafindo,2005.

Hoogerwerf, A, Isi Dan Corak-Corak Kebijakan (Overhead Beleid), Terjemah R.L.L.Tobing, Jakarta: Erlangga, 1973.

Ishak, Awang. Farouk, Strategi Pembangunan Kawasan Perbatasan Kalimantan Timur, Samarinda: Pemerintah Propinsi Kalimantan Timur, 2009.

Ishikawa, Naboru, Between Frontiers: Nation and Identity in a Southeast Asian Borderland, Singapura: NUS press, 2008.

J. Ulaen, Alex, et. Al., (editor: Endjat Djaenuderajat), Sejarah Wilayah Perbatasan Miangas-Filipina 1928-2010: Dua Nama Satu Juragan, Jakarta: Gramata Publishing, 2012.

Kelompok Kerja Kewiraan Lemhanas, Pendidikan Kewiraan (Buku Induk Bahan Pendidikan Kewiraan/Kewarganegaraa), Jakarta: Diterbitkan dengan Kerjasama Dirjen Dikti Depdikbud, 1995.

Kemitraan Partership, Rekomendasi Kebijakan Pengelolaan Perbatasan Indonesia, Jakarta: Penerbit : Kemitraan Bagi Pembaruan Tata Pemerintahan (Partnership), 2011.

Krieken, Peter J Van, ed., Health,Migration And Return, The Hague: T.M.C.Asser Press, 2001.

Kristianus et.al., Tim Pengkaji (Partnership), Rumusan Rekomendasi Kebijakan Pengelolaan Perbatasan Di Kalimantan Barat, Jakarta: Kemitraan bagi Pembaruan Tata Pemerintahan, 2011.

Krsitof, The Nature of Fronteir and Boundaries, AAAG.Vol.49. 
Kumorotomo, Wahyudi, Desentralisasi Fiskal (Politik dan Perubahan Kebijakan 19742004), Jakarta: Kencana, 2008.

Bandung: Binacipta,1970.

Lemhanas Republik Indonesia, Bunga Rampai Wawasan Nusantara I, Jakarta: Firma Skala \& Lemhanas, 1981.

Lo, Fu-chen dan Byung-Naik Song, Industrial restructuring of the ESEA (East and Southheast Asian) Economies, Kuala Lumpur, Asian Pacific Development Centre, 1987.

Marzuki, Suparman, Tragedi Politik Hukum HAM, Yogyakarta : Pustaka Pelajar \& PUSHAM UII, 2011.

Masyur Effendi, A., Tempat Hak-hak Asasi Manusia dalam Hukum Internasional/ Nasional, Bandung : Penerbit Alumni, 1980.

- - - . Naskah Persiapan UUD 1945, Jilid Pertama, Jakarta : Yayasan Prapantja, 1995.

MD, Moh. Mahfud, Politik Hukum di Indonesia, Edisi Revisi, Jakarta: PT. RajaGrafindo Persada, 2009.

- - -. Pergulatan Politik dan Hukum, Yogyakarta-Jakarta: PT. Gama Media- The Ford Foundation, 1998.

- - - Perdebatan Hukum Tata Negara Pasca Amandemen Konstitusi, Jakarta: LP3ES, 2007.

- - -. Bahan Kuliah Program Pascasarjana Fakultas Hukum UII Yogjakarta, Tanpa tahun.

- - - . Politik Hukum di Indonesia, Jakarta: LP3ES, 1998.

- - -. Pergulatan Politik Dan Hukum Di Indonesia, Yogyakarta: Gama Media, 1999.

Muhamad, Simela Victor, "Batas Wilayah Negara Dalam Perspektif Hukum Internasional, Dalam Batas Wilayah Dan Situasi Perbatasan Indonesia : Ancaman Terhadap Integritas Teritorial" dalam Poltak Partogi Nainggolan, ed., Jakarta: Tiga Putra Utama, 2004.

Nasution, Adnan Buyung, Aspirasi Pemerintahan Konstitusional di Indonesia:Studi Sosio Legal atas Konstituante 1956-1959, Jakarta: Pustaka Utama Grafiti, 1982. 
Nasution, Arif, Orang Indonesia di Malaysia (Menjual Kemiskinan membangun Identitas), Yogyakarta, Pustaka Pelajar, 2001.

Nonet, Philippe Philippe dan Philippe Selznick, Law and Sociaty in Transition: Towards Responsive Law, New York: Harper \& Row, 1978.

Notonegoro, Beberapa Hal Mengenai Falsafah Pancasila, Jakarta: Pantjuran Tudjuh, 1975.

Partnership for Governance Reform, "Kebijakan Pengelolaan Kawasan Perbatasan Indonesia”, Partnership Policy Paper, Edisi No. 2, 2011.

Pusat Kajian Administrasi Internasional Lembaga Administrasi Negara, Laporan Hasil Penelitian "Kajian Manajemen Wilayah Perbatasan Negara, Jakarta: Desember, 2004.

Rawls, John, A Thory Of Justice, Cambridge Mass: Harvard University press, 1972.

Soemasdi, Hartati, Pemikiran Tentang Filsafat Pancasila, 1992.

Sumardiman, Adi, Wilayah Indonesia dan Dasar Hukumnya, Buku I Perbatasan Indonesia-Papua New Guinea, Jakarta: PT. Pradnya Paramita, 1992.

Sutisna, Sobar, ed., Pandangan Wilayah Perbatasan Indonesia, Cibinong: Pusat Pemetaan Batas Wilayah Bakosurtanal, 2004.

Tim Partnership for Governance Reform, Kebijakan Pengelolaan Kawasan Perbatasan Indonesia, The Jakarta: Partnership for Governance Reform , 2011.

Villanueva, Klass, Teknik Dalam Penentuan Perbatasan RI-Timor Timur, Jakarta: Tanpa Penerbit, 2001.

Victor Muhamad, Simela, Batas Wilayah Negara Dalam Perspektif Hukum Internasional, Dalam Batas Wilayah Dan Situasi Perbatasan Indonesia : Ancaman Terhadap Integritas Teritorial, editor : Poltak Partogi Nainggolan, Jakarta : Tiga Putra Utama, 2004.

Wuryandari, Genewati,dkk, Keamanan di Perbatasan Indonesia-Timor Leste (Sumber Ancaman dan Kebijakan Pengelolaannya),Yogyakarta : Pustaka Pelajar \& P2PLIPI,2009.

Zain, Siti Noorehan Mohd, Mengelola Perbatasan Indonesia di Dunia Tanpa Batas, Yogyakarta: Graha Ilmu, 2010.

Zein,Yahya Ahmad, HakWarga Negara Diwilayah Perbatasan (Perlindungan Hukum Hak Atas Pendidikan dan Kesehatan), Yogyakarta : Liberty, 2017. 


\section{Jurnal \&Artikel}

Abubakar, Mustafa, "Analisis Kebijakan Pemanfaatan Pulau-Pulau Kecil Perbatasan" (Kasus Pulau Sebatik, Kabupaten Nunukan, Kalimantan Timur) Dalam Buku Menata Pulau-Pulau Kecil Perbatasan,Jakarta : Kompas. 2006.

Anwar, Donillo, "Potensi dan Nilai Strategis Batas antara Negara: ditinjau dari aspek hukum perjanjian internasional" Dalam Mengoptimalkan Peran Dan Fungsi Survey Pemetaan Dalam Pengelolaan Batas Wilayah, Bakosurtanal bekerjasama dengan Depdagri, Forum komunikasi dan koordinasi teknis batas wilayah, Bogor,2002.

\section{Peraturan Perundang-Undangan}

Indonesia.Undang-Undang Dasar 1945

Indonesia. Undang-Undang Nomor 7 Tahun 1950 tentang Perubahan Konstitusi Sementara Republik Indonesia Serikat menjadi Undang-Undang Dasar Sementara Republik Indonesia.

Indonesia. Undang Undang No. 19 Tahun 1961 tentang Persetujuan Atas Tiga Konvensi Jenewa Tahun 1958 Mengenai Hukum Laut di sahkan pada tanggal 6 September 1961, Jakarta : LN 1961/276; TLN NO. 2318.

Indonesia. Undang-Undang No.6 Tahun 1973 tentang Perjanjian Antara Indonesia Dan Australia Mengenai Garis-Garis Batas Tertentu Antara Indonesia Dan Papua New Guinea.

Indonesia. Undang-undang Nomor 3 Tahun 2002 tentang Pertahanan Negara

Indonesia. Undang-Undang No.20 Tahun 2003 tentang Sistem Pendidikan Nasional.

Indonesia. Undang-Undang No.34 Tahun 2004 tentang Tentara Nasional Indonesia.

Indonesia. Undang-Undang No.11 Tahun 2005 tentang Pengesahan International Covenant On Economic, Social And Cultural Rights (Kovenan Internasional Tentang Hak-Hak Ekonomi, Sosial Dan Budaya).

Indonesia. Undang-Undang Nomor 17 Tahun 2007 tentang Rencana Pembangunan Jangka Panjang Nasional Tahun 2005 - 2025.

Indonesia. Undang-Undang Nomor 43 Tahun 2008 tentang Wilayah Negara.

Indonesia. Peraturan Pemerintah Nomor 38 Tahun 2007 tentang Pembagian Urusan Pemerintahan antara Pemerintah, Pemerintahan Daerah Provinsi dan 
Pemerintahan Daerah Kabupaten/Kota; Lembaran Daerah Tahun 2007 Nomor 82; Tambahan Lembaran Negara Nomor 4737.

Indonesia. Peraturan Presiden Republik Indonesia Nomor 5 Tahun 2010 tentang Rencana Pembangunan Jangka Menengah Nasional Tahun 2010 - 2014.

Indonesia. Peraturan Presiden No.12 Tahun 2010 tentang Badan Nasional Pengelola Perbatasan (BNPP).

Indonesia. Permendagri No.31 Tahun 2010 tentang Organisasi dan Tata Kerja BNPP.

Indonesia. Peraturan Menteri Dalam Negeri Nomor 2 Tahun 2011 tentang Pedoman Pembentukan Badan Pengelola Perbatasan Di Daerah.

Indonesia. Peraturan Badan Nasional Pengelola Perbatasan Nomor 3 Tahun 2011 tentang Rencana Aksi Pengelolaan Batas Wilayah Negara Dan Kawasan Perbatasan Tahun 2011. 